\title{
DOES THE NATURE OF INTERACTIONS WITH HIGHER EDUCATION INSTITUTIONS INFLUENCE THE INNOVATIVE CAPABILITIES OF CREATIVE FIRMS? THE CASE OF A SOUTH- WESTERN NORWEGIAN COUNTY
}

\author{
Giuseppe Calignano ${ }^{1,2}$, Kari Jøsendal ${ }^{3}$ \\ ${ }^{1}$ Department of Geography and Regional Research, University of Vienna \\ ${ }^{2}$ Centre for Innovation Research - UiS Business School, University of Stavanger, Norway \\ ${ }^{3}$ Rogaland County Council, Stavanger, Norway
}

Manuscript received: October 25, 2018

Revised version: November 21, 2018

\begin{abstract}
Calignano G., JøSendal K., 2018. Does the nature of interactions with higher education institutions influence the innovative capabilities of creative firms? The case of a south-western Norwegian county. Quaestiones Geographicae 37(4), Bogucki Wydawnictwo Naukowe, Poznań, pp. 67-79. 2 tables.

ABSTRACT: Our study contributes to a limited body of literature and aims to examine the type and frequency of linkages between creative industries and higher education institutions (HEIs). The objective of our study is to investigate the extent to which various types of linkages contribute to enhanced innovative capabilities in creative industries. Based on a qualitative research design and a case study carried out in a peripheral south-western Norwegian county, our empirical analysis shows that HEIs are generally not very relevant partners and that other actors are mainly involved in innovation dynamics. As clarified and discussed in the paper, this finding largely depends on some specific characteristics of HEIs, the form of knowledge primarily employed by creative firms (symbolic knowledge base), and the cultural divergence between the two spheres.
\end{abstract}

KEY WORDS: creative industries, higher education institutions, knowledge transfer, innovative capability

Corresponding author: Giuseppe Calignano, Department of Geography and Regional Research, University of Vienna, Universitaetsstrasse 7, 1010 Vienna, Austria

Centre for Innovation Research - UiS Business School, University of Stavanger, P.O. Box 8600 Forus, 4036 Stavanger,

Norway, e-mail: giuseppe.calignano@univie.ac.at

\section{Introduction}

Higher education institutions (HEIs), such as universities and research centres, are important to local economies as such institutions serve as sources of local employment and produce skilled workforces and new knowledge. HEIs are also important nodes in distributed innovation surroundings. In addition to educating students and conducting basic research, HEIs may offer vital support to firms in their innovation processes (Cohen, Levinthal 1990; Chesbrough 2006). Firms with the ability to establish connections with
HEIs may be more prone to innovate (Kaufmann, Tödtling 2001; George et al. 2002). However, research on the linkages between HEIs and firms has primarily concentrated on technological development in high-tech sectors and large enterprises. In recent years, only a few studies have explored knowledge transfer and exchange between HEIs and creative industries ${ }^{1}$ (Mould et al. 2009;

1 Creative industries include advertising, architecture, the art and antiques market, crafts, design, designer fashion, film and video, interactive leisure software, music, the performing arts, publishing, software and computer services, television and radio (DCMS 2000). 
Ferguson 2014; Jones et al. 2014; Taylor et al. 2014). The aim of this paper is to contribute to the limited literature by examining the main opportunities for and impediments to interactions between the two spheres in knowledge transfer and exchange dynamics. In addition, previous studies have not sufficiently discussed the extent to which firms in creative industries effectively internalise external knowledge and apply it to commercial ends. This study will attempt to fill this gap in the literature by investigating how interaction with HEIs may stimulate the capability to innovate.

Firm-HEI interactions may range from using open information sources to engaging in innovation cooperation. Therefore, being part of an innovation system is a necessary but not a sufficient criterion for sustaining and enhancing innovative capabilities. For HEIs to influence regional innovations, they need to be embedded in a regional ecosystem that can absorb research and exploit knowledge in order to innovate (Florida et al. 2006). The use of knowledge to enhance innovation is contingent on the absorptive capacity of users (Cohen, Levinthal 1990). Absorptive capacity thus moderates the relationship between interaction with HEIs and innovative capabilities. The level of absorptive capacity may be critical. High levels of absorptive capacity in firms increase opportunities to search for and engage in collaborative activities with universities located at a distance (Laursen et al. 2011). Furthermore, larger firms tend to establish linkages with HEIs more frequently than smaller firms because they often have the resources to develop the required capabilities to internalise new knowledge (Laursen, Salter 2006). Attaining high levels of absorptive capacity may pose a challenge to firms in creative industries.

Similarly, a knowledge base (Asheim, Gertler 2005) that predominantly characterises specific industries and physical proximity to HEIs influence the level and quality of interactions. In this regard, a symbolic knowledge base mainly characterises creative industries, whose features include a high degree of embeddedness in the local socio-cultural context and high sensitivity to proximity with potential partners, including HEIs (Martin, Moodysson 2011).

The structural characteristics of creative industries feature mostly small firms operating in social network markets (Potts 2011). The traditionally examined linkages between HEIs and firms do not fully capture the variety of roles of HEIs in the knowledge economy (Mowery, Sampat 2005). Hence, knowledge flows from HEIs to industry may be misjudged, as they are assigned overly narrow roles in the innovation process (Hawkins et al. 2007). Researchers must examine and measure new types of knowledge inputs, such as forming networks and stimulating interaction, increasing capacity for scientific and technical problem solving, increasing the stock of knowledge and stimulating social knowledge (Hawkins et al. 2007). Based on the above considerations, the following research questions are addressed in this paper: How frequently do creative firms interact with HEIs and what is the nature of such relationships? What are the main opportunities for and impediments to creative firm-HEI interactions? Accordingly, how do interactions with HEIs influence the innovative capabilities of creative firms?

The remainder of the paper is organised as follows. First, the paper defines creative industries and describes the characteristics of innovation in these industries. The next section reviews the literature and presents the model of analysis. Subsequently, the data and methodology are described, and the results are presented and systematised. Finally, a discussion and concluding remarks are provided.

\section{Theoretical framework}

\section{Definition and characteristics of creative industries}

Creative industries are defined as "those industries which have their origin in individual creativity, skill and talent and which have a potential for wealth and job creation through the generation and exploitation of intellectual property" (DCMS 1998). This concept has been widely used in international studies and reports, such as those conducted by UNCTAD $(2008,2010)$.

Innovation in creative industries has characteristics that considerably differ from those of innovation in manufacturing industries. Examples include i) soft innovations (Chapain et al. 2010), ii) the rearrangement of musical concerts or introduction of new ways of interacting with the 
audience (Castaner, Campos 2002), and iii) innovations resulting in a new style generating both a new product and a new meaning attached to the product (Cappetta et al. 2006).

Soft innovation is defined as "changes in either goods or services that primarily impact sensory perception and aesthetics rather than function appeal" (Chapain et al. 2010: 17) and therefore does not emphasise the functionality of products. Two types of innovation are referenced. The first type is innovation in products that are not generally considered functional in nature but instead offer aesthetic appeal and/or appeal to the senses or the intellect, such as music, books, films, or the products of creative industries. The second type is aesthetic innovations in industries where the output is functional, such as furniture, cars and food. Brand images and marketing innovations are also examples of soft innovation.

Castaner and Campos define artistic innovation as "the programming of work that is new to the field" (2002: 32). Innovation is a complete departure from existing conventions (ibid.). Two dimensions of innovation are described, which are content and form. A method for content innovation is multidisciplinarity, which involves combining multiple art forms. An example of artistic innovation and form is how organisations design interactions with the audience during a performance.

Stylistic innovation is a concept connected to the aesthetic and symbolic value of style, which is becoming more important for technological products. Stylistic innovation is defined as follows: "a stylistic innovation results from the reassignment of social meaning to an existing product and/or from a change in the aesthetic characteristics of a product generating both a new product - from a physical point of view - and a new meaning" (Cappetta et al. 2006). The main point here is that although stylistic innovation is a change in the assigned social meaning (ibid.), the physical form may also change. Style is the prime product in the fine fashion industry.

Because many innovations in creative industries are aesthetic in character and appeal to the senses, they are difficult to measure and quantify, thus complicating analyses of the capability to innovate in creative industries when the result is immaterial in character. How HEIs can contribute to innovations in creative industries is not well documented. One issue to address is how integrated these industries are in the local network where HEIs are generally important nodes, and whether such integration is actually a decisive condition in the innovation process.

\section{Innovative capability}

Creativity translated into new products, processes and images is highlighted as a prerequisite for being innovative and thus for securing competitiveness. Innovative capability indicates that innovations contain core elements and processes regardless of the industry or firm (Lawson, Samson 2001). Innovative capability can be conceptualised and operationalised in different manners since it can be considered a meta-capability including various competences in several areas. Similarly, no single mode is used to foster innovative capability (ibid.). Thus, innovative capability combines resources in an organisation dedicated to creating value for customers and connections in the market.

Given these considerations and following Rajapathirana and Hui (2018), with the term 'innovative capability', we refer to firms' ability to innovate. To be more precise, innovative capability can be viewed as firms' capacity to develop new products that satisfy market needs (product innovation) or to apply novel technologies to produce new products (process innovation) (ibid.). In addition, we argue that innovative capability can influence other spheres such as marketing and organisational innovation (OECD 2005). One of the major aims of our study is to examine whether and how interactions with HEIs contribute to this specific aspect. More specifically, through our qualitative research design, we are interested in understanding whether prospective interactions and related knowledge exchange with HEIs help creative firms enhance their existing innovative capabilities.

\section{Creative industries and linkages with HEIs}

Linkages with HEIs may take various forms. The Oslo Manual (OECD 2005) differentiates between open information sources, the acquisition of knowledge and technology, and innovation cooperation (Table 1). Open information source characteristics imply no interaction with the 
Table 1. Types of linkages, degree of interaction and costs of HEI-firm relationships.

\begin{tabular}{|c|c|c|c|}
\hline & Open information source & $\begin{array}{c}\text { Acquisition of technology } \\
\text { and knowledge }\end{array}$ & Innovation cooperation \\
\hline \multirow[t]{4}{*}{ Forms of linkages } & reading publications & consulting & joint research projects \\
\hline & attending conferences & licensing & \\
\hline & \multirow[t]{2}{*}{ personal relationships } & access to facilities and equipment & \\
\hline & & contract research & \\
\hline Degree of interaction & no interaction & interaction not required & active cooperation \\
\hline \multirow[t]{2}{*}{ Costs } & does not require purchase & require purchase & time \\
\hline & & & exploitation of internal resou \\
\hline
\end{tabular}

Source: OECD (2005).

external environment and do not impose costs on firms. The one-directional knowledge flow is explicit in character. The acquisition of technology and knowledge includes purchasing external knowledge and technology, such as machinery. Such acquisition may also include hiring employees or using contract research. These forms of linkages require purchase. At the other end of the scale is innovation cooperation, which is characterised by active cooperation between the parts involving a two-way knowledge flow that largely contains tacit knowledge. The costs associated with innovation cooperation may stem from the time devoted by employees within the firm and equipment purchasing.

However, the linkages in Table 1 do not fully capture the variety of roles of HEIs in the knowledge economy (Mowery, Sampat 2005). Quantitative indicators have been emphasised, but the quality of links have been given less attention. Hence, knowledge flows from HEIs to industry may be misjudged, as they are assigned overly narrow roles in the innovation process (Hawkins et al. 2007). Research must therefore examine new types of knowledge inputs, such as forming networks and stimulating interaction, increasing the capacity for scientific and technical problem solving, increasing the stock of knowledge and stimulating social knowledge (Hawkins at al. 2007). In the knowledge economy, intangibles such as tacit knowledge are recognised as the primary sources of competitive advantage (Teece 2000).

From a systemic view point, recent studies conducted at the intersection between management and geographical analysis have introduced new concepts such as Mode 3 and Quadruple Helix model of innovation (Carayannis, Campbell 2009) with the aim of expanding the renowned
Mode 2 and Triple Helix Model respectively (Etzkowitz, Leydesdorff 1997; Etzkowitz, Leydesdorff 2000). Among other things, these new models back the importance of combining different knowledge modes in multi-level innovation systems. Moreover, in addition to the triad university-industry-government (Etzkowitz, Leydesdorff 1997), a 'fourth helix' of innovation can be associated to terms such as 'media', 'creative industries', 'culture', 'values', 'life styles' and 'art', thus considering the so-called 'creative class' (Florida 2004) as an extremely relevant factor in regional innovation dynamics (Carayannis et al. 2018).

\section{Symbolic knowledge base, modes of innovation and physical proximity}

Science, Technology and Innovation (STI) and Doing, Using and Interacting (DUI) are the two concepts usually adopted by scholars to identify and examine different modes of innovation (Jensen et al. 2007). Based on this distinction, STI mode refers to the generation and application of - primarily codified - scientific knowledge, especially in industries such as chemicals, pharmaceuticals, biotechnology and nanomaterials. This mode of innovation is mainly anchored in the so-called linear model of innovation (Bush 1945, Maclaurin 1953), and R\&D investment, human capital and scientific partners are considered key variables. Conversely, the exchange of tacit knowledge through experience and know-how allowing firms to solve specific problems represent the main characteristics of DUI mode (e.g. Fitjar, Rodrìguez-Pose 2015).

Different modes of innovation and knowledge bases characterising different industries are intertwined. According to a taxonomy proposed 
by Plum and Hassink (2014), based on previous works of Asheim and Gertler (2005) and Moodysson et al. (2008), creative industries are primarily characterised by a symbolic knowledge base. Knowledge creation and exchange in creative industries generally occurs through interactive and informal processes aiming to solve specific problems. This type of firm receives inputs from youth and street or fine cultures, and such firms' interactions with members of the same professional communities are generally considered more relevant than cooperation with HEIs. As outlined above, tacit knowledge represents a peculiar trait of creative firms that is not accessible elsewhere. Know-how (a style, look or sound) fostered by an urban/local scene or atmosphere contributes to creating milieus of creative industries (Hall 2000). Accordingly, interactions with partners (including HEIs, if any) are expected to be localised due to high sensitivity to spatial distance shown by firms characterised by a symbolic knowledge base (e.g., Asheim, Gerlter 2005; Moodysson et al. 2008). As explained above, absorptive capacity (Cohen, Levinthal 1990) is another element that influences the frequency, intensity and geography of knowledge ties (Laursen, Salter 2006).

\section{Methods and results}

\section{Empirical setting}

This paper reports on a study performed in Rogaland, a peripheral county situated in the south-western region of Norway. As a result of the development of the oil and gas industry since the 1960s, Rogaland is one of the most dominant industrial regions in Norway. One-third of the employment in the county depends on the oil and gas sector, rendering Rogaland heavily dependent on oil price and investment in the sector (Ekeland 2017).

Approximately 3,800 firms fit into the category of creative industries, employing approximately 12,000 people (Jøsendal et al. 2008), which reflects the latest overview of the industries in the county. The figure amounts to a substantial share (approximately 11\%) of the total employment in Rogaland. However, individual businesses are small. About $72 \%$ of the firms are sole entrepreneurs, and $57 \%$ consist of between one and four man-years (ibid.). Smallness may represent a challenge in the search for knowledge and ideas when operating in complex networks due to restricted resources. Larger firms have both financial and human capital, enabling them to navigate in networks.

In 2004 and 2008, surveys of the creative industries in Rogaland were conducted. Both surveys focused on how firms in the creative industries relate to external actors (Jøsendal et al. 2004, 2008). In both surveys, informal networks were rated as more important than formal networks. About $65 \%$ of the respondents in 2008 stated that colleagues were by far the most important source of professional development in the creative industries. The second most important source of professional development was customers, while R\&D and public authorities were ranked as least important. In 2004, the results were nearly the same, as R\&D and public authorities were not considered important sources of professional development. These findings raise a question regarding the extent to which the indicators that most studies use to analyse links between firms and HEIs are relevant to creative industries.

Approximately $22 \%$ of the firms were established between 2004 and 2006, and 24\% were set up in the period 2007-2008. In 2004, about 35\% of the respondents reported that the main reason for establishing the company was personal interest, whereas $32 \%$ of the respondents started firms based on needs on the market. In 2008, nearly $50 \%$ of the respondents stated that their personal interest was the main cause for the start-up. Furthermore, only $10 \%$ of respondents' decisions were based on market demand. Demand-driven explanations for entrepreneurs have declined, possibly due to a growing economy and because market research concerning books, films or a new design is not possible. In both surveys, the businesses expressed the need for knowledge in marketing and creativity.

\section{Data collection}

The qualitative design of this study is based on interviews with twelve individual businesses in creative industries. Transparency in this study is secured by describing and documenting the research procedures (Guba, Lincon 2005; Yin 
Table 2. Firm category and field of production.

\begin{tabular}{|l|l|c|c|}
\hline \multicolumn{1}{|c|}{ Category } & \multicolumn{1}{|c|}{ Field of production } & Start-up year & Employees \\
\hline \multirow{5}{*}{ Audio-visual } & film and video production & 2003 & 6 \\
\cline { 2 - 4 } & film and video production & 2003 & 9 \\
\cline { 2 - 4 } & film and video production & 1999 & 14 \\
\cline { 2 - 4 } & literature and film & 2001 & Part-time 2 \\
\hline \multirow{5}{*}{ Graphic and/or industrial design } & graphic, industrial design, project management & 2003 & 2 \\
\cline { 2 - 4 } & industrial design & 2003 & 2 \\
\cline { 2 - 4 } & graphic design, multimedia, GIS & 2000 & 16 \\
\cline { 2 - 4 } Art or clothing design & graphic design & 1995 & 2 \\
\hline \multirow{5}{*}{} & jewellery and art design & 1982 & 2 \\
\cline { 2 - 4 } & clothing design & 1998 & 2 \\
\cline { 2 - 4 } & clothing design & 2006 & 1 \\
\cline { 2 - 4 } & clothing design & 297 & 2 \\
\hline
\end{tabular}

Source: own study based on interviews.

2011). Interviews were conducted with representatives from the following categories of creative industries: a) audio-visual, b) graphic and industrial design, and c) art or clothing design (Table 2). In firms with more than one employee, we interviewed the manager, and one interview was conducted with each representative. The data were organised thematically in a data matrix. The rationale for selecting categories a, $\mathrm{b}$ and $\mathrm{c}$ is related to their significance in terms of the amount of business in the region, and because of the emphasis and support that these categories receive from local authorities, particularly the film industry.

The relationship between the researcher and the interviewee was flexible, and follow-up questions were posed (Yin 2011). The interviews were conducted within the frame of a conversation to encourage two-way interaction. The interviews occurred in the interviewees' environment and lasted approximately one to two hours. The questions were open ended and invited the interviewee to speak freely about the topics that were presented. In this study, interviews are used as a primary data source and to secure validation; two scientists participated in nine interviews and the data analysis. During each interview, one researcher led the conversation while the other typed the interview on a portable computer. For the interviews that were conducted by only one researcher, handwritten notes were taken and transcribed after the interview. The analysis is based on the explanations and language of the participants and the particular setting of the interview. An interview guide and general information about the study objective were sent to the informants before the interview. The questions were constructed based on the following sections: i) general information about the firm, ii) the degree of collaboration with HEIs and other actors, iii) the manner in which this collaboration occurred, iv) impediments to collaboration, and v) the areas in which they would like to collaborate.

The interviews were concluded when the saturation point was reached, i.e. when new respondents did not add relevant information to the previous ones (Baker, Edwards 2012). In this regard, Guest et al. (2006) argue that if the objective of a research "is to describe a shared perception, belief, or behavior among a relatively homogeneous group, then a sample of twelve [respondents, authors' note] will likely be sufficient". Following this approach and adopting the logic of 'thin rationality' (according to which the mechanisms revealed by our study could be similarly observed elsewhere; see Bengtsson, Hertting 2014 for a broader discussion), we believe that our research design based on 12 qualitative interviews with experts in the field is reasonably reliable and potentially applicable to similar social and geographical contexts.

\section{Sample}

The data consist of interviews within the following categories of creative industries: ten firms are micro firms with fewer than ten employees, and two are small firms with fewer than 50 employees (according to the definition of SMEs by European Commission (2006)). Table 2 provides a summary of business categories, start-up years and the numbers of employees. 


\section{Results}

This study aims to determine the frequency of interactions between creative firms and HEIs, the main opportunities and impediments affecting such linkages, and how interactions with HEIs influence the innovative capabilities of creative firms. Below, the findings are presented following the various research questions addressed in the present paper.

\section{Innovation processes}

Being innovative in shooting a film and choosing how to convey the message and the product appearance (i.e. style) are important. Style is an apparent driver of innovation. One of the clothing design businesses $(\mathrm{J})$ emphasised the necessity "[...] to create [an own] identity through style [...] not as much new material and shapes". By 'own identity', the informant means a specific recognisable style. This designer is preoccupied with configuring national heritage in a modern innovative style using both colours and a combination of different materials and textures.

Other clothing designers also referred to being identified by a specific style. In relation to a new collection, another informant $(\mathrm{K})$ described the process after having conducted research on fashion trends, including designs, colours, materials and structures through trend magazines and catalogues, and trade exhibitions. "I select what fits in to my style [... I] always also go back and look at former trends. In addition, you should have your own style - it is an interpretation of everything". The abovementioned business also emphasised the commercial nature of business, specifically in aiming to avoid high production costs.

Combining ecological material, art and design as the central elements is important to another business. This designer may be categorised in the haute couture segment of the design industry, reflecting innovativeness in an artistic sense. The business has an explicit focus on social responsibility in both its aim and production and has thus realised necessary innovations in both production processes and techniques. The informant emphasised that being artistic is not a specific aim in terms of producing limited quantities of each design.
Informant $\mathrm{E}$ makes products of artistic value, including the actual design, structure, texture and finish. "We spent a lot of time researching how to get the right finish, structure etc. [...]. We combine innovative design with new finishes and structures". The business is innovative with the materials used, which include fabric and metal.

One graphical and industrial design business emphasised the importance of collaborating with customers and participating in the entire product development process to promote innovation. As mentioned by all informants in this business category, the firms offer project management as a service that they prefer to use and deliver competently. This management ensures control over the entire design process. For example, according to the informant, the abovementioned business employs a process in which the firm was able to produce an innovative design and concept in relation to a food product but relied on the contractor to use its expertise in producing the food content.

\section{Interaction with HEIs}

The interviews focused on whether and how the various businesses interact with HEIs. Informant I collaborated with students. "The collaboration did not concern our products directly but was about the art field in general and specifically about music and commonalities with our artistic work. We enjoyed getting to know the students". The question that the informant considered during the collaboration period concerned how collaboration could influence design.

However, other informants stated that despite the lack of contact with HEIs, they have considered establishing such contact. This response indicates that an informant may want to teach at a university. Another informant (D) perceives some challenges ahead, stating that "there is no interaction today, but it may be a reality in the future. It is not easy to find out about interaction. I don't know how private enterprises can collaborate with the university".

Reading articles and attending seminars were also mentioned, but these activities were not undertaken on a regular basis. Customers may act as a point of connection with HEIs, and some also rent equipment from the university. One informant has informal contact with HEIs through customers. At one point, the informant engaged 
with a student, but after this engagement, the informant rejected requests from students. Generally, the informants reported that contact with students is time consuming and that businesses do not have the capacity for this task. For some informants, physical facilities may also be insufficient.

When asked about the sources of information that are vital for generating new ideas and products, the informants presented a range of examples, but few of them included HEIs. The most important sources were listed as suppliers, customers, competitors, colleagues, the internet, trend magazines and fashion magazines. Conferences and seminars supply some information to the businesses.

Informant $\mathrm{J}$ in the clothing design category declared the following: "I have never thought of getting information from HEIs. The information from the university is not good enough. Perhaps we have not been curious enough either". However, fashion houses provide knowledge and tend to give advice to newcomers. According to informant $\mathrm{D}$, the work of designers is rather isolating, which is a disadvantage because it prevents actors from receiving feedback from colleagues or other qualified sources.

Nevertheless, informant $\mathrm{K}$ in the clothing industry stated as follows: "There are not many people I can learn from. After high school, there is not much further education. The only option is to go to trend seminars". This statement was underlined by an informant who admitted the following: "Usually, our work is very isolated. You need feedback and networks".

How businesses in creative industries relate to their surroundings when seeking new knowledge is clarified by informant A in the following way: "Collecting information is very rarely organised. It depends on each producer. We work a lot and travel a lot. We study the products of our competitors. HEIs are not a source of information". In this case, the informant points to the arbitrary aspect of gathering information. Clearly, HEIs are not a relevant knowledge source.

Using the internet as an information source was underlined by interviewee B: "The internet is an important source of information. It inspires in a broad sense. The visual entertainment industry that surrounds us is also a source of information. The internet is increasing its role as source of innovation. $R \& D$ is not a source of information. I use my network to create a story".

For instance, the university may help with sales. As one informant (I) declared, "We cannot stretch in all directions. This is the biggest weakness with this kind of business". Furthermore, HEIs may contribute methods that could benefit small businesses. Because of the small size of the business discussion, partners are needed for actors to discuss strategies. Interaction may also include topics such as sales and communication with the public. Informant F suggested, "if the university had a way to tie together businesses in small design milieus, a workshop could be arranged; it would be very exciting if the university and the designers could interact more".

An interest in engaging students was also expressed. Technical knowledge is required for producing graphical profiles, and competence is desired in the field of design and fabrics. More direct contact is demanded, as exemplified by one informant: "I think a lot of people are interested in the on-going research. Maybe we just don't see what is going on. We need more direct contact".

Informant $\mathrm{F}$ was very optimistic in her statement: "I see only possibilities. There are no limitations. The designers have a huge amount of competence. In the region, the designers could meet and engage in developing methods, marketing, how to cooperate with HEIs to the benefit of all parts". This statement corroborates comments from other informants stating that they often work alone. In one business, employees' desire for an informal style implies that making a phone call is more relevant that writing a letter to HEIs in the case of interaction. This business has contacted the university about engaging students. At the time of the interview, the business was in need of directors and producers. In one situation described by a representative from another business, the firm needed to make a step forward, find new markets and develop new ideas; the question is how HEIs can contribute within these areas. Finally, an informant declared that it would be interesting to establish a tripartite collaboration involving HEIs, culture and traditional business.

The data analysis shows that nine of twelve firms had marginal or no linkages with HEIs. According to the interviewees, one-way interactions rather than actual knowledge exchange 
were relevant when the HEIs played a role in increasing the innovative potential of firms. In this regard, articles published in professional magazines and related websites are considered among the most important sources of knowledge, although some interviewees consider actual and potential informal contacts similarly relevant. Informant I reported engaging in collaborative activities with students as an important source of knowledge, although another informant found that this type of activity was not particularly satisfying in terms of acquiring new relevant knowledge. Finally, seminars are another reported source of knowledge that indirectly involve exchanges with HEIs. However, all of these activities are not undertaken on a regular basis. Customers may also act as mediators between firms and HEIs. Furthermore, renting equipment was also presented as a link to HEIs, which will enable a business to establish contact with persons at HEIs and therefore open some doors that may be useful on later occasions. Thus, the interviews indicated that open information sources are used, implying marginal or no interaction.

\section{Impediments to productive cooperation with HEIs and the types and geography of knowledge sources}

The interviews reveal scepticism towards HEIs, as illustrated by informant G: "It is all about prejudice. We think research is slow. But it has also to do with ourselves, we are not good enough, we prioritise other things, we do not take advantage of the potential benefits". Informant B expressed the following: "There are no principal reasons why we don't interact with HEIs. It is not relevant, not offensive enough. $R \& D$ is passé. It could have been interesting if they were in front. There is too little communication". The informant argued that HEIs are not up-to-date on new knowledge.

Arguments indicating cultural differences include excessive bureaucracy that kills innovativeness, the reluctance of university employees to cooperate with businesses, and the separate worlds in which HEIs and businesses live. Moreover, the expectation was that firms want results quickly, whereas work at HEIs implies a longer time span.

With regard to the education level, seven of the informants (i.e. managers and/or owners of the businesses) reported having higher education degrees, whereas five had spent one or two years at private institutes. Five informants had more than twenty years of experience, five had approximately ten years of experience, and two had fewer than five years of experience. Work experience constitutes tacit knowledge, which is complementary to codified knowledge, and represents a vital part of the cognitive dimension in businesses. Prior related knowledge in the firm, both tacit and codified, in a collaborative situation with HEIs facilitates the learning process.

The data reveal variation in the level of openness to external collaboration. The overall impression was that collaborative activities consist of alliances with national and international suppliers or partners. Informant L indicated that "production is taking place in Turkey and China. We have engaged in an alliance with a person concerning sales. For the first time, we're working with a photographer from Oslo. We also work with a very good stylist and a model from the region".

The lack of linkages with external institutions or organisations was explained by $\mathrm{D}$ as follows: "It is difficult to establish contacts without costs. We have no network; we don't know how things work in the publisher business. But we will not be able to move on without supportive contacts".

The general impression from the interviews is that businesses have close relations with colleagues within the same industry, businesses in other industries and freelancers. However, such businesses are less involved in formal networks; they tend to be engaged in specific customer and producer networks.

When seeking external competence, these businesses prefer local partners if the appropriate competence can be found in the region. As informant L stated, "It is necessary to engage professionals from Oslo, but most of all, I would like to cooperate with qualified people from the region. The expertise in question is more experienced than the locals". Local partners are favoured as a result of their physical proximity, which is beneficial concerning both time and costs. However, due to a lack of relevant expertise in the region, they must turn to milieus outside the region. Personal networks such as friends and acquaintances were also mentioned as knowledge sources. 
Although several businesses reported engaging in or making use of a formal network, the interviews indicated that informal networks are more important to most of the informants. Such networks serve as an arena for obtaining information and establishing links with other art fields. Exhibitions are of special importance. The informants find inspiration and ideas to use in the innovation process primarily through informal networks. Indirectly, these networks may include news from research and HEIs.

The need for meeting places thus emerges. Combining resources may spur collective activity in the fields of sales, marketing and trend competence. However, individual firms do not have sufficient resources to accept such an arrangement. A facilitator is required, and this role may be fulfilled by HEIs. However, some segments of the production process are not suitable for collaboration. Protecting an idea until the product is due for presentation on the market is crucial. This consideration is especially important in relation to the uniqueness of the product and the creative phase of the production process. Considering the need to protect business secrets, collaborative activities are more appropriate towards the end of the production process in the fields of promotion, marketing, sales, exhibitions and education.

\section{Systematising our findings}

As specified in the introduction, our paper aims to understand how frequently creative firms interact with HEIs and to identify the main opportunities and impediments in actual and potential interactions. Moreover, we aim to determine the potential influence of such interactions on the innovative capabilities of the surveyed creative firms. Our study has been conducted in the Norwegian context, specifically, in Rogaland, i.e. a peripheral and strongly oil-dependent county located in south-western Norway (Fitjar, Rodrìguez-Pose 2011).

Identifying trends is a crucial ingredient of innovation processes in creative industries. However, efforts to create trends and styles are even more important. Collaboration with customers is also a significant action in striving to produce innovative products as well as developing a cultural understanding of the societal environment. Nonetheless, our analysis indicates that searching for knowledge and information to generate ideas is largely an arbitrary activity. Routines for knowledge seeking have not been established. Few, if any, routines exist for assimilating and applying knowledge. Dividing innovation processes into specific components is therefore complicated, and this complexity underlines that innovation is not a linear process in creative industries.

The businesses in this study approach HEIs primarily through open information sources, which imply marginal or no interaction between the parties in question. According to the Oslo Manual (OECD 2005), this method of gaining knowledge is passive, and the knowledge is mainly codified. Open information sources are essentially one-way communication practices whose aim is primarily to become acquainted with and use knowledge rather than actively participating in creating new knowledge. As a consequence, HEIs are situated on the outskirts of the innovation networks in which creative industries operate. HEIs are not integrated within the network ecology, and knowledge transfer appears to be limited. Overall, our findings suggest that the impact of actual interactions with HEIs on the innovative capabilities of firms is negligible.

The informants indicated two main categories of linkages that would meet their needs and positively affect innovation processes. First, interactions with HEIs are considered potentially positive in activities such as sales, communication and marketing. Second, HEIs are invited to facilitate arenas for inter- and intra-industrial collaboration. Both types of linkages enable businesses to recognise and more importantly exploit new knowledge in a more systematic and presumably helpful manner. Notably, however, none of these activities are directly related to creativity due to the characteristics of HEIs (excessive bureaucracy, lack of up-to-date knowledge in various creative fields, etc.). Similarly, the need for secrecy facilitates potential cooperation with HEIs in the late phases of the production process (see below for a further discussion on these aspects).

The primary sources of knowledge in innovation processes are suppliers, customers, colleagues, competitors and the internet. Linkages with knowledge sources involve establishing alliances, participating in informal networks and attending exhibitions. These relations may support 
exchanging tacit knowledge and stimulate twoway communication and knowledge co-creation. Nevertheless, the data do not indicate a systematic search for knowledge or routines for acting upon new knowledge. Personal relations are crucial for fostering knowledge networks, and a lack of cooperation with geographically close partners is evident even though such regional interactions would be very welcomed.

However, the lack of routines and strategies might not be a liability. The seemingly arbitrary activities of firms concerning the external environment could confirm the social network markets within which the creative industries operate. The traditional categories used in analysing linkages between industry and HEIs do not apply to the case of the creative industries.

The observed resistance to collaborating with HEIs can be explained by a variety of additional factors. First, transaction costs in the form of both financial resources and human capital are high. The returns from devoting money and time do not correspond to the costs. Such a use of resources is not productive, according to some of the informants. Second, firms report receiving a lack of information from HEIs, perhaps because of their low awareness of the activities conducted in academic institutions, and this lack of information flow from HEIs motivates the search for knowledge from other sources.

An additional explanation for the unwillingness to link with HEIs is the presumed cultural differences. The strongest argument concerning cultural divergence is that although businesses are eager to achieve results in product development within a short time span, HEIs do not have the necessary speed in their work processes. There is a discrepancy in the willingness and ability to devote time to projects. Businesses depend on being a first comer in the marketplace, and collaboration with HEIs does not support such a strategy. An additional argument presented involves the fear of being burned with bureaucracy within HEIs, which would consequently kill creativity and innovativeness.

\section{Discussion and concluding remarks}

This study aims to fill the knowledge gap concerning linkages between HEIs and firms in creative industries. Our findings suggest that the categories of linkages used in studies of manufacturing industries do not apply to creative industries, and that knowledge transfer from HEIs to firms in creative industries is fairly limited, which may in turn hamper the strengthening of competitive advantages in these industries. As a result, more research is undoubtedly needed to determine how HEIs and creative industries can establish linkages that benefit both parties.

Our analysis provides positive contributions and clearly confirms speculations in the limited literature addressing the topic of interactions between creative firms and HEIs (Mould et al. 2009; Taylor et al. 2014). In fact, the peculiar type of innovation process based on aesthetic or intangible value largely benefits from indirect knowledge sources, e.g. open innovation (Chesbrough 2006) and different actors (e.g. customers and suppliers). Although this result is apparently not particularly original and supports the main arguments of scholars in innovation studies (for details on the topic of a symbolic knowledge base, see Asheim, Gertler 2005), our study shows that knowledge flows are not geographically localised but especially involve more distant partners, which contrasts with suggestions in the literature on differentiated knowledge bases. In fact, industries characterised by symbolic knowledge bases (i.e. creative industries) generally show high sensitivity to proximity to potential collaborators.

Creating new ideas aimed at producing signs and symbols does not occur in a sequential process. Rather, such activity is characterised as a social phenomenon. R\&D does not play a critical guiding role in firms in creative industries. However, it is overly simplistic to refer to creative processes as arbitrary; they are simply different. Knowledge is largely associated with something that can be identified and categorised as tacit and codified. Digital technology is a crucial tool for firms, and the traditional categorisation of knowledge has become inadequate. Regarding the circumstances in which firm-HEI interactions are established, the face-to-face aspect may still be important, but the face-to-virtual world appears to be equally central (on this topic see Bathelt, Turi 2011). The innovation - or, rather, the manifestation - of the creative process is of immaterial character and is therefore not quantifiable. 
Information technology is an integral part of the innovation process. Tacit and codified knowledge therefore become more problematic in such terms.

In addition, we argue that the (primarily quantitative) variables used to measure absorptive capacity (Cohen, Levinthal 1990) in the manufacturing sector are not similarly useful in the case of creative industries. If we consider the definitions and applications generally adopted in the literature, absorptive capacity has a limited role in informing creative processes in the surveyed firms. However, the characteristics of creative firms (e.g. being small and micro-sized, organising their work primarily as projects, generally lacking the resources necessary to establish their own R\&D departments) suggest that absorptive capacity should be operationalised differently in future studies examining connections between HEIs and creative firms (e.g. familiarity, trust, human capital, networking). In simple terms, we argue that the mainly tacit and aesthetic dimension of innovation in creative industries requires methodologies other than those used in traditional studies of absorptive capacity. We believe that future academic research should carefully consider this critical issue.

Our study has limitations that must be duly acknowledged. We interviewed twelve highly knowledgeable informants who viewed the question in focus from various perspectives. In any case, the informants presented their subjective answers to these questions, perhaps leading to bias. Another limitation of the research is the lack of financial resources. As a result, a small number of firms and categories within the creative industries were included in the study. This limitation may weaken the conclusions in the sense that other cases could produce nuances or different emphases in the interpretation of data.

An additional limitation of this study is that we did not interview employees from HEIs. Thus, only opinions from the creative industries are presented, yielding a one-sided story. Furthermore, the firms in this study are micro-enterprises. Interviews with larger firms may provide a more detailed and varied picture of relations between creative industries and HEIs, as large firms have more resources and are thus able to approach HEIs in a more strategic and intentional manner.
Similarly, the geographical context is fundamental in empirical case studies on creative firms. Being located in a larger and dynamic city may lead to different results compared to our analysis conducted in a peripheral and marginally innovative area such as Rogaland in Norway (for details on the positive role of agglomeration economies in creative industries see Lazeretti et al. 2013)

Finally, we used a static approach since we studied the phenomenon at one point in time. A longitudinal approach would clarify how firms evolve within a networked society.

\section{References}

Asheim B.T., Gertler M.S., 2005. The geography of innovation: Regional innovation systems. In: Fagerberg J., Mowery D.C., Nelson R.R. (eds), The Oxford handbook of innovation. Oxford University Press, Oxford: 291-317.

Bakhshi H., Freeman A., Higgs P., 2013. A dynamic mapping of the UK's creative industries. Nesta, London.

Baker S.E., Edwards R., 2012. How many qualitative interviews is enough? Expert voices and early career reflections on sampling and cases in qualitative research. National Centre for Research Methods Review Paper. http://eprints.ncrm. ac.uk/2273/4/how_many_interviews.pdf, (accessed: 21 November 2018)

Bengtsson B., Hertting N., 2014. Generalization by mechanism: Thin rationality and ideal-type analysis in case study research. Philosophy of the Social Sciences 44(6): 707732. DOI: $10.1177 / 0048393113506495$

Bush V., 1945. Science - The endless frontier. A report to the president on a program for postwar scientific research. National Science Foundation, Washington.

Cappetta R., Cillo P., Ponti A., 2006. Convergent designs in fine fashion: An evolutionary model for stylistic innovation. Research Policy 35(9): 1273-1290. DOI 10.1016/j.respol.2006.02.009.

Carayannis E.G., Campbell D.F.J., 2009. “Mode 3" and "Quadruple Helix": Toward a 21st century fractal innovation ecosystem. International Journal of Technology Management 46: 201-234. DOI: 10.1504/IJTM.2009.023374

Carayannis E.G., Grigoroudis E., Campbell D.F.J., Meissner D., Stamati D., 2018. The ecosystem as helix: An exploratory theory-building study of regional co-opetitive entrepreneurial ecosystems as Quadruple/Quintuple Helix Innovation Models. RED Management 48(1): 148-162. DOI: $10.1111 / \mathrm{radm} .12300$

Castañer X., Campos L., 2002. The determinants of artistic innovation: Bringing in the role of organizations. Journal of Cultural Economics 26(1): 29-52. DOI 10.1023/A:1013386413465.

Chapain C., Cooke P., de Propris L., Macneil S., Mateo Garcia J., 2010. Creative clusters and innovation. Putting creativity on the map. NESTA, London, UK.

Chesbrough H., 2006. Open innovation: A new paradigm for understanding industrial innovation. In: Chesbrough H., Vanhaverbeke W., West J. (eds), Open innovation, re- 
searching a new paradigm. Oxford University Press, Oxford: $1-12$.

Cohen W.M., Levinthal D.A., 1990. Absorptive capacity: A new perspective on learning and innovation. Administrative Science Quarterly 35(1): 128-152. DOI $10.2307 / 2393553$.

DCMS, 1998. Creative industries mapping document. Department of Culture Media and Sport UK Government, London.

Ekeland A., 2017. Sysselsetting i petroleumnæringene og relaterte næringer (Employment in the oil industry and related industries) 2016. Statistics Norway 2017/27.

Etzkowitz H., Leydesdorff L., 1997. Universities in the global economy: A triple helix of academic-industry-government relations. Croom Helm, London.

Etzkowitz H., Leydesdorff L., 2000. The dynamics of innovation: From national systems and "Mode 2" to a triple helix of university-industry-government relations. Research Policy 29: 109-123. DOI: 10.1016/S0048-7333(99)00055-4

European Commission, 2006. The new SME definition. User guide and model declaration. European Commission, Brussels.

European Commission, 2010. European competitive report 2010. European Commission, Brussels.

Ferguson M., 2014. Knowledge exchange between universities and the creative industries in the UK: A case study of current practice. Industry and Higher Education 28(3): 177-183.

Fitjar R.D., Rodríguez-Pose A., 2015. Networking, context and firm-level innovation: Cooperation through the regional filter in Norway. Geoforum 63: 25-35. DOI 10.1016/j.geoforum.2015.05.010.

Florida R., 2004. The rise of the creative class and how it's transforming work, leisure, community and everyday life. Basic Books, New York.

Florida R., Gates G., Knudsen B., Stolarick K., 2006. The university and the creative economy. George Mason University, Fairfax, VA.

George G., Zahra S.A., Wood D.R., 2002. The effects of business-university alliances on innovative output and financial performance: A study of publicly traded biotechnology companies. Journal of Business Venturing 17(6): 577-609. DOI 10.1016/S0883-9026(01)00069-6.

Guest G., Bunce A., Johnson L., 2006. How many interviews are enough? An experiment with data saturation and variability. Field Methods 18(1): 59-82. DOI: $10.1177 / 1525822 \times 05279903$

Hawkins R.W., Langford C., Sidhu K., 2007. University research in an 'innovation society'. In: OECD, Science, technology and innovation indicators in a changing world: Responding to policy needs. Paris: 171-192.

Jensen M.B., Johnson B., Lorenz E., Lundvall B.Å., 2007. Forms of knowledge and modes of innovation. Research Policy 36(5): 680-693. DOI 10.1016/j.respol.2007.01.006.

Jøsendal K., Berg C., Solheim A., Stevenson B., 2008. Kreative næringer $i$ Rogaland 2008 (Creative Industries in Rogaland 2008). Stavanger. IRIS Report 2009/004.

Jøsendal K., Berg C., Westnes P., Claussen T., 2004. Kreative næringer $i$ Rogaland (Creative Industries in Rogaland). Stavanger. Rogalandsforskning Report 2004/169.

Kaufmann A., Tödtling F., 2001. Science-industry interaction in the process of innovation: The importance of boundary-crossing between systems. Research Policy 30(5): $791-$ 804. DOI 10.1016/S0048-7333(00)00118-9.
Laursen K., Reichstein T., Salter A., 2011. Exploring the effect of geographical proximity and university quality on university-industry collaboration in the United Kingdom. Regional Studies 45(4): 507-523. DOI 10.1080/00343400903401618.

Laursen K., Salter A., 2006. Open for innovation: The role of openness in explaining innovation performance among UK manufacturing firms. Strategic Management Journal 27(2): 131-150.

Lawson B., Samson D., 2001. Developing innovation capability in organisations: A dynamic capabilities approach. International Journal of Innovation Management 5(3): 377-400.

Lazeretti L., Boix R., Capone F., 2013. Why do creative industries cluster? In: Lazzeretti L. (ed.), Creative industries and innovation in Europe. Concepts, measures and comparative case studies. Routledge: Regional Studies Association.

Maclaurin W.R., 1953. The sequence from invention to innovation and its relation to economic growth. The Quarterly Journal of Economics 67(1): 97-111.

Martin R., Moodysson J., 2011. Innovation in symbolic industries: The geography and organization of knowledge sourcing. European Planning Studies 19(7): 1183-1203. DOI 10.1080/09654313.2011.573131.

Moodysson J., Coenen L., Asheim B., 2008. Explaining spatial patterns of innovation: Analytical and synthetic modes of knowledge creation in the medicon valley life-science cluster. Environment and Planning A: Economy and Space 40(5): 1040-1056. DOI 10.1068/a39110.

Mould O., Vorley T., Roodhouse S., 2009. Realizing capabilities-academic creativity and the creative industries. Creative Industries Journal 1(2): 137-150. DOI 10.1386/ cij.1.2.137_1.

Mowery D.C., Sampat B.N., 2005. Universities in national innovation systems. In: Fagerberg J., Mowery D.C., Nelson R.R. (eds), The Oxford handbook of innovation. Oxford University Press, Oxford: 209-239.

OECD, 2005. Oslo manual. Guidelines for collecting and interpreting innovation data. OECD Publishing, Paris.

Plum O., Hassink R., 2014. Knowledge bases, innovativeness and competitiveness in creative industries: The case of Hamburg's video game developers. Regional Studies, Regional Science 1(1): 248-268. DOI 10.1080/21681376.2014.967803.

Potts J., 2011. Creative industries and economic evolution. Edward Elgar, Cheltenham, UK.

Rajapathirana R.P.J., Hui Y., 2018. Relationship between innovation capability, innovation type, and firm performance. Journal of Innovation \& Knowledge 3(1): 44-55. DOI 10.1016/j.jik.2017.06.002.

Taylor C., Comunian R., Smith D.N., 2014. The role of universities in the regional creative economies of the UK: Hidden protagonists and the challenge of knowledge transfer. European Planning Studies 22(12): 2456-2476. DOI 10.1080/09654313.2013.790589.

Teece D.J., 2000. Managing intellectual capital: Organizational, strategic, and policy dimensions. Oxford University Press, Oxford.

UNCTAD, 2008. Creative economy report 2008. The challenge of assessing the creative economy: towards informed policy-making. United Nations, New York, NY.

UNCTAD, 2010. Creative economy report 2010. Creative economy: A feasible development option. United Nations, New York, NY

Yin R.K., 2011. Qualitative research from start to finish. The Guilford Press, New York, NY. 